\title{
Implementasi Problem Based Learning berbantuan Google Classroom Untuk Meningkatkan Prestasi Belajar Matematika
}

\author{
Evi Dwi Krisna*, Ni Luh Putu Mery Marlinda \\ STMIK STIKOM INDONESIA, Denpasar, Bali 80225 \\ *Email: evidwikrisna@gmail.com
}

DOI: https://doi.org/10.33369/pendipa.4.3.91-97

\begin{abstract}
[Implementation of Problem Based Learning Model with Google Classroom to Improve Mathematics' Learning Outcome] The aim of this study was to determine the improvement of students' mathematics learning outcomes with the implementation of Problem Based Learning Education Model with Google Classroom support. The type of research was classroom action research involving subjects as many as 30 students of IT class in STIMIK STIKOM Indonesia. This research was conducted in two cycles, each of which consists of planning, action, observation, evaluation, and reflection. The analysis technique used was descriptive statistical analysis. The results showed that the implementation of Problem Based Learning Education Model supported by Google Classroom succeeded in improving learning outcomes. This is evident from the average score of students' mathematics learning outcomes for cognitive and affective domains. In the cognitive domains, average score was 60.70 for the early reflection and increase by $11.25 \%$ to 66.83 in the first cycle, increase by $9.27 \%$ to 73.03 in the second cycle. The average score of students' mathematics learning outcomes for the affective domain was 2.83 (quite good category). At the stage of early reflections increased by $18.4 \%$ to 3.27 (good categories) in the first cycle, and increased by $12.23 \%$ to 3.67 (good categories) in the second cycle.
\end{abstract}

Keywords: Problem based learning, google classroom, mathematics, learning outcome.

\begin{abstract}
ABSTRAK
Tujuan dilaksanakannya penelitian ini adalah untuk mengetahui peningkatan prestasi belajar matematika mahasiswa setelah diterapkannya model pembelajaran Problem Based Learning berbantuan Google Classroom. Penelitian ini termasuk penelitian tindakan kelas yang melibatkan subyek sebanyak 30 mahasiswa kelas TI di STMIK STIKOM Idonesia. Penelitian ini dilaksanakan dalam dua siklus, yang masing-masing terdiri dari perencanaan, tindakan, observasi, evaluasi, dan refleksi.Teknik analisis data yang digunakan mengunakan analisis statistik deskriptif. Hasil penelitian menunjukkan bahwa implementasi model Problem Based Learning Berbantuan Google Classroom berhasil meningkatkan prestasi belajar matematika mahasiswa. Terlihat dari rata-rata skor prestasi belajar dari ranah kognitif dan afektif yang mengalami peningkatan. Untuk ranah kognitif, yaitu 60,07 pada tahap refleksi awal meningkat sebesar $11,25 \%$ menjadi 66,83 pada siklus I, meningkat sebesar 9,27\% menjadi 73,03 pada siklus II. Sedangkan nilai rata-rata hasil untuk ranah afektif yaitu yaitu 2,83 (kategori cukup baik) pada tahap refleksi awal meningkat sebesar 18,4\% menjadi 3,27 (kategori baik) pada siklus I, meningkat sebesar 12,23\% menjadi 3,67 (kategori baik) pada siklus II.
\end{abstract}

Kata kunci: Problem based learning, google classroom, matematika, prestasi belajar. 


\section{PENDAHULUAN}

Pendidikan merupakan pondasi dasar dalam mencetak sumber daya manusia yang berkualitas untuk kemajuan dan perkembangan suatu negara. Di Indonesia, Sistem Pendidikan Nasional diatur dalam UU Nomor 20 Tahun 2003, pasal 3, disebutkan bahwa pendidikan nasional berfungsi mengembangkan kemampuan dan membentuk watak serta peradaban bangsa yang bermartabat dalam rangka mencerdaskan kehidupan bangsa. Matematika merupakan salah satu bidang studi yang sangat penting bagi peserta didik maupun bagi pengembangan bidang keilmuan yang lain (Suherman, 2003), dan merupakan alat utama untuk memberikan cara berpikir, yaitu menyusun pemikiran yang jelas, tepat, teliti, dan taat azaz. Jadi Matematika adalah salah satu bidang ilmu yang berpotensi memainkan peranan strategis dalam menyiapkan sumber daya manusia.

Namun prestasi belajar mahasiswa STMIK STIKOM Indonesia pada mata kuliah matematika masih belum optimal. Berdasarkan hasil wawancara dengan dosen-dosen mata kuliah matematika dan pengamatan selama proses pembelajaran, rendahnya prestasi belajar mahasiswa salah satunya dipengaruhi oleh kurangnya kemampuan pemecahan masalah matematika, yang dipengaruhi oleh kurangnya inisiatif mahasiswa mempelajari materi terlebih dahulu di rumah dan lebih memilih untuk menunggu penjelasan dari dosen. Mahasiswa cenderung menghapalkan rumus-rumus daripada memahami konsep sehingga apabila diberikan soal atau permasalahan yang sedikit berbeda dengan soal yang diberikan sebelumnya, mahasiswa kebingungan menyelesaikannya.

Menyikapi hal tersebut, pembelajaran inovatif yang dirasa dapat memberi pengaruh terhadap prestasi belajar mahasiswa adalah model pembelajaran Problem-Based Learning (PBL). PBL merupakan model pembelajaran yang mengorganisasikan pembelajaran di sekitar pertanyaan dan masalah, melalui pengajuan situasi kehidupan nyata yang autentik dan bermakna, yang mendorong mahasiswa untuk melakukan penyelidikan dan inkuiri, dengan menghindari jawaban sederhana, serta memungkinkan adanya berbagai macam solusi dari situasi tersebut (shofiyah, 20018). Model pembelajaran ini menurut Sudiarta dalam (Evi, 2013) merupakan model pembelajaran yang mengutamakan proses penyelesaian masalah dan tidak semata melihat kebenaran jawaban akhir. Selama proses pemecahan masalah, siswa membangun pengetahuan serta mengembangkan keterampilan pemecahan masalah dan keterampilan self-regulated learner. Menurut Arends (dalam Evi 2013), langkah kerja (sintak) model Problem Based Learning (PBL) dalam pembelajaran adalah sebagai berikut:

1) Orientasi pada masalah; 2) Mengorganisasikan peserta didik untuk belajar; 3) Membimbing penyelidikan individu maupun kelompok; 4) Mengembangkan dan menyajikan hasil karya; dan 5) Menganalisis dan mengevaluasi proses pemecahan masalah. Kelebihan dari $P B L$ adalah utamanya untuk membantu pebelajar dalam membangun kemampuan berfikir kritis, pemecahan masalah, dan intelektual mereka, Selain hal tersebut model pembelajaran ini juga dapat memberikan kesempatan pada pebelajar untuk mengaplikasikan pengetahuan yang mereka miliki dalam dunia nyata, membantu pebelajar mengembangkan pengetahuan barunya, bertanggung jawab dalam pembelajaran yang mereka lakukan dan juga dapat mendorong untuk melakukan evaluasi sendiri baik terhadap hasil maupun proses belajarnya.

Internet merupakan perkembangan teknologi saat ini yang memungkinan mahasiswa dengan mudah dan cepat mengakses dan mencari bahan pembelajaran baik berupa artikel maupun publikasi ilmiah sebagai literature dan referensi dalam memudahkan pembelajaran. Internet juga mendukung berbagai media platform atau aplikasi pembelajaran yang dapat diakses melalui telepon gengam sehingga praktis dan mudah digunakan. Hasil penelitian Gheytasi et al., (2015) menunjukan bahwa pebelajar yang banyak berinteraksi dengan aplikasi di telepon genggam lebih mudah memahami isi teks bacaan.

Salah satu media aplikasi yang banyak dimanfaatkan sebagai media pendukung pembelajaran adalah Google Classroom, yang merupakan salah satu dari layanan Google For Education. Google Classroom adalah platform pembelajaran multifitur yang dikembangkan oleh google untuk sistem pembelajaran yang bertujuan untuk menyederhanakan pembuatan, pendistribusian dan penilaian maupun evaluasi materi dan tugas-tugas dengan sistem/konsep 
ramah lingkungan dengan pembatasan pemakaian kertas (paperless) (Ahmad, 2019).

Google Classroom dapat diakses melalui 2 cara yaitu melalui website dan aplikasi. Berdasarkan website resmi dari Google, Google Classroom ini memberikan beberapa manfaat seperti: 1) Kelas dapat disiapkan dengan mudah; pengajar dapat menyiapkan kelas dan mengundang peserta didik serta asisten pengajar. Kemudian dalam suasana pembelajaran virtual, mereka dapat berbagi informasi, memberikan tugas, pengumuman dan pertanyaan; 2) Menghemat waktu dan kertas; pengajar dapat membuat suasana kelas secara virtual, memberikan tugas, berkomunikasi dan melakuan pengelolaan, semuanya di satu tempat; 3) Pengelolaan yang lebih baik; peserta didik dapat melihat tugas di halaman tugas maupun di kalender kelas. Semua materi otomatis tersimpan dalam folder Google Drive; 4) Penyempurnaan interaksi dalam komunikasi dan pemberian masukan; pengajar dapat membuat tugas, mengirim pengumuman dan memulai diskusi kelas secara langsung. Pengajar dan peserta didik dapat berbagi materi dan berinteraksi satu sama lain Pengajar juga dapat melihat dengan cepat siapa saja yang sudah dan belum menyelesaikan tugas, serta langsung memberikan nilai dan masukan secara real-time.; 5) Aman dan terjangkau; dapat diakses luas dan disediakan secara gratis.

Beberapa studi sebelumnya mempelajari tentang efektivitas dari Google Classroom dalam proses pembelajaran. Pertama adalah penelitian oleh Sabran (2018) tentang keefektifan $e$ - learning dengan google classroom sebagai media pembelajaran termasuk dalam kategori cukup efektif dengan persentase tingkat kecenderungan sebesar $77,57 \%$. Disamping itu yang kedua adalah penelitian yang dilakukan oleh Muslik (2019) Google classroom Sebagai Alternatif Digitalisasi Pembelajaran Matematika Di Era Revolusi Industri 4.0. Diperoleh hasil bahwa peranan Google Classsroom sebagai model pembelajaran matematika di era digital cukup diapresiasi sebesar $83 \%$. Serta menurut maharani dalam penelitiannya (2019), dengan menggunakan Google Classroom, maka kemampuan pemecahan masalah mahasiswa menjadi lebih baik.
Jadi penggunaan Google Classroom sebagai media pembelajaran memungkinkan terjadinya "suasana kelas virtual' yang memungkinkan proses belajar mengajar tidak dibatasi ruang dan waktu. Mahasiswa dapat mengakses materi dari dosen dimana saja dan kapan saja, sehingga memudahkan mahasiswa untuk belajar. Dosen juga dapat dengan mudah mengumpulkan, mengkoreksi dan memeriksa tugas dari mahasiswa dimana saja dan kapan saja.

Dengan menggunakan model pembelajaran PBL dan didukung media berbasis teknologi, diharapkan proses pembelajaran menjadi lebih efektif dan optimal. Berdasarkan uraian di atas, peneliti mengadakan penelitian tentang "Implementasi Model Pembelajaran Problem Based Learning Berbantuan Google Classroom untuk Meningkatkan Prestasi Belajar Pada Mata Kuliah Matematika".

\section{METODE PENELITIAN \\ Waktu dan Lokasi Penelitian}

Penelitian ini berlangsung dari bulan Maret sampai Juli 2020 di STMIK STIKOM Indonesia Rancangan Penelitian

Jenis penelitian ini adalah penelitian tindakan kelas (classroom action research). Menurut Sumini (2015), penelitian tindakan kelas merupakan cara strategis bagi pengajar untuk memperbaiki proses pembelajaran di kelas Penelitian ini dirancang menjadi dua bagian kegiatan yaitu refleksi awal dan pelaksanaan penelitian. Pelaksanaan tindakan diawali dengan persiapan dilanjutkan dengan dua siklus. Setiap siklus terdiri dari 4 (empat) tahapan yaitu (1) perencanan, (2) tindakan, (3) observasi dan evaluasi, dan (4) refleksi Arikunto (2008).

\section{Teknik Pengumpulan Data}

Teknik pengumpulan data dilakukan melalui observasi, catatan lapangan, tes prestasi (kognitif) yakni kemampuan pemecahan masalah dan afektif serta kuisioner untuk mengetahui respon mahasiswa. Tes yang digunakan untuk mengumpulkan data prestasi belajar matematika adalah tes pemecahan masalah berbentuk soal uraian (essay) yang terdiri dari 5 butir soal. Tes ini dilaksanakan pada saat akhir siklus I, akhir siklus II, Sebelum digunakan, tes ini diuji validitas isi dan validitas susunannya oleh validator. 


\section{Metode Analisis Data}

Teknik analisa data yang digunakan adalah metoda kuantitatif. Indikator keberhasilan dilihat dari meningkatnya rata - rata ranah kognif dan afektif mahasiswa. Skor rata - rata ranah kognifif dan afektif juga di analisis menggunakan statistik diskriptif.

\section{HASIL DAN PEMBAHASAN}

Berdasarkan hasil penelitian yang dilaksanakan dengan pengimplementasian model pembelajaran Problem Based Learning dengan berbantuan Google Clasroom yang dilaksanakan dengan 2 siklus, yang dirangkum pada Tabel 1, Tabel 2 dan Gambar 1 sampai 3, terlihat adanya peningkatan prestasi belajar dari skor rata-rata hasil belajar ranah kognitif dan ranah afektif, dimana program ini sudah berjalan sesuai dengan yang ditetapkan dan memberi efek positif terhadap hasil/outcome pembelajaran.

Tabel 1. Hasil Matematika Mahasiswa Ranah Kognitif

\begin{tabular}{|c|c|c|c|c|c|c|c|}
\hline \multirow{2}{*}{ No } & \multirow{2}{*}{ Kategori } & \multicolumn{2}{|c|}{ R. Awal } & \multicolumn{2}{|c|}{ Siklus I } & \multicolumn{2}{|c|}{ Siklus II } \\
\hline & & $\mathrm{F}$ & $\mathrm{P}$ & $\mathrm{F}$ & $\mathrm{P}$ & $\mathrm{F}$ & $\mathrm{P}$ \\
\hline 1. & $\begin{array}{l}\text { Belum } \\
\text { Tuntas }\end{array}$ & 16 & $\begin{array}{c}53,33 \\
\%\end{array}$ & 10 & $\begin{array}{c}33,33 \\
\%\end{array}$ & 4 & $\begin{array}{c}13,33 \\
\%\end{array}$ \\
\hline 2. & Tuntas & 14 & $\begin{array}{c}46,67 \\
\%\end{array}$ & 20 & $\begin{array}{l}66,67 \\
\%\end{array}$ & $\begin{array}{l}2 \\
6 \\
\end{array}$ & $\begin{array}{c}86,67 \\
\%\end{array}$ \\
\hline \multicolumn{2}{|c|}{ Jumlah } & 30 & $100 \%$ & 30 & $100 \%$ & $\begin{array}{l}3 \\
0\end{array}$ & $100 \%$ \\
\hline \multicolumn{2}{|c|}{ Rata-Rata Skor } & \multicolumn{2}{|c|}{60,07} & \multicolumn{2}{|c|}{66,83} & \multicolumn{2}{|c|}{73,03} \\
\hline \multicolumn{2}{|c|}{ Daya Serap } & \multicolumn{2}{|c|}{$60.07 \%$} & \multicolumn{2}{|c|}{$66,83 \%$} & \multicolumn{2}{|c|}{$73,03 \%$} \\
\hline
\end{tabular}

Tabel 2. Hasil Ranah Afektif

\begin{tabular}{|c|c|c|c|c|c|c|c|}
\hline \multirow{2}{*}{ No } & \multirow{2}{*}{ Kat. } & \multicolumn{2}{|c|}{ R. Awal } & \multicolumn{2}{|c|}{ Siklus I } & \multicolumn{2}{|c|}{ Siklus II } \\
\hline & & $\mathrm{F}$ & $\mathrm{P}$ & $\mathrm{F}$ & $\mathrm{P}$ & $\mathrm{F}$ & $\mathrm{P}$ \\
\hline 1. & $\begin{array}{l}\text { Sangat } \\
\text { Kurang } \\
\text { Baik }\end{array}$ & - & - & - & - & - & - \\
\hline 2. & $\begin{array}{l}\text { Kurang } \\
\text { Baik }\end{array}$ & 2 & $6,67 \%$ & - & - & - & - \\
\hline 3. & $\begin{array}{l}\text { Cukup } \\
\text { Baik }\end{array}$ & 7 & $23,33 \%$ & 5 & $\begin{array}{l}16,6 \\
7 \%\end{array}$ & 1 & $3,33 \%$ \\
\hline 4. & Baik & 16 & $53,33 \%$ & 16 & $\begin{array}{l}53,3 \\
3 \% \\
\end{array}$ & 15 & $50 \%$ \\
\hline 5. & $\begin{array}{l}\text { Sangat } \\
\text { Baik }\end{array}$ & 5 & $1,77 \%$ & 9 & $\begin{array}{l}30 \\
\%\end{array}$ & 14 & $46,67 \%$ \\
\hline \multicolumn{2}{|c|}{ Jumlah } & 30 & $100 \%$ & 30 & $\begin{array}{c}100 \\
\%\end{array}$ & 30 & $100 \%$ \\
\hline \multicolumn{2}{|c|}{ Rata-Rata } & \multicolumn{2}{|r|}{2,76} & \multicolumn{2}{|c|}{3,27} & \multicolumn{2}{|r|}{3,67} \\
\hline \multicolumn{2}{|c|}{ Kategori } & \multicolumn{2}{|c|}{ Cukup } & \multicolumn{2}{|c|}{ Baik } & \multicolumn{2}{|r|}{ Baik } \\
\hline
\end{tabular}

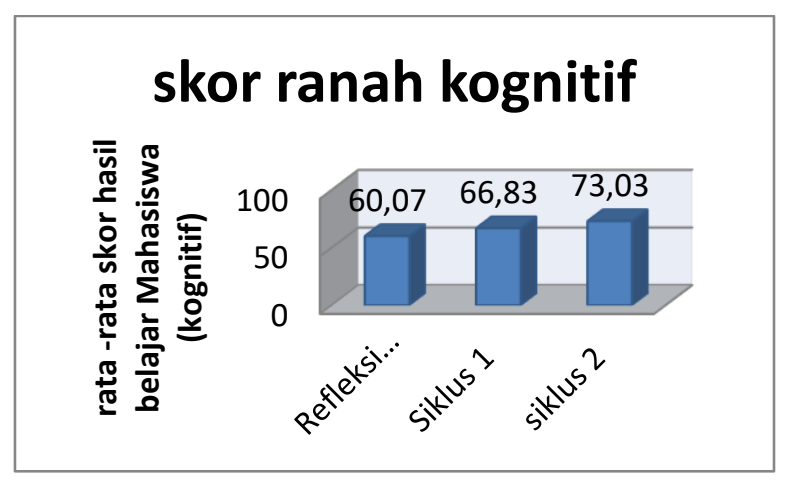

Gambar 1. Peningkatan Rata-Rata Skor Mahasiswa Ranah Kognitif

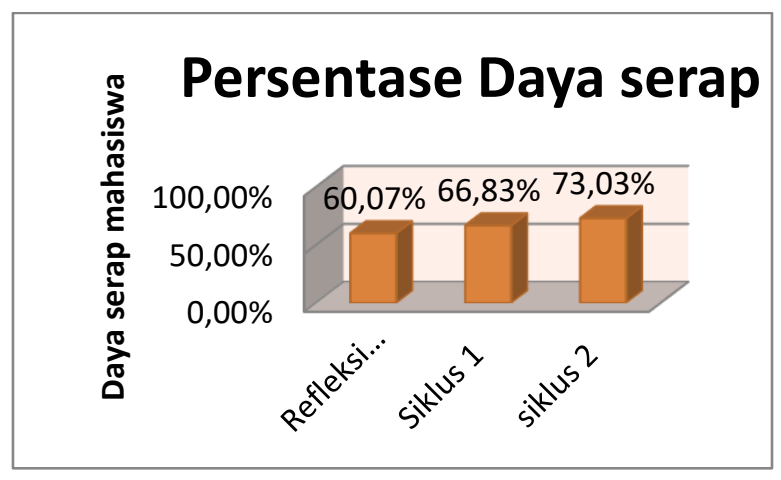

Gambar 2. Peningkatan Daya Serap Mahasiswa

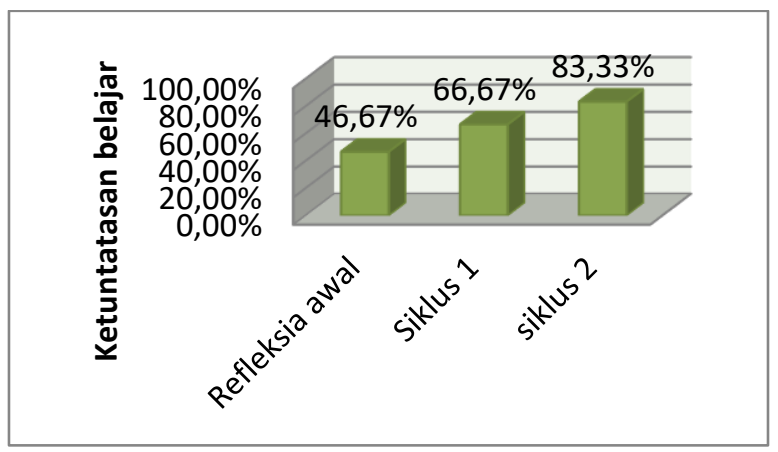

Gambar 3. Peningkatan Ketuntasan Belajar Mahasiswa

Adapun seperti yang telah dijelaskan sebelumnya, bahwa program dari penelitian ini dilakukan sebanyak 2 siklus, demikian juga penilaian dilakukan tiap siklusnya untuk dibandingkan dengan nilai awal dan dievaluasi perkembangan pada tiap siklusnya sehingga didapatkan fluktuasi nilai sebagai indikator keberhasilan dan efektivitas pengimplementasian model 
pembelajaran Problem Based Learning dengan berbantuan Google Clasroom dapat meningkatkan prestasi belajar mahasiswa dalam bidang ilmu matematika. Dari hasil penelitian ini, berdasarkan hasil analisis data pada siklus I, menunjukakan adanya peningkatan prestasi belajar matematika dibandingkan pada refleksi awal, meskipun peningkatan tersebut belum memenuhi kriteria baik. Hal ini terlihat dari rata rata skor ranah kognitif yaitu 60,07 pada tahap refleksi awal, kemudian terjadi peningkatan sebesar $11,25 \%$ menjadi 66,83 pada siklus I, dengan persentase ketuntasan $66,67 \%$ yang dikategorikan belum mencapai indikator keberhasilan. Sedangkan untuk ranah afektif sudah memenuhi indikator keberhasilan yang ditetapkan yakni kategori baik.

Secara umum kegiatan pembelajaran sudah berlangsung dengan cukup baik pada proses pembelajaran siklus I. Namun demikian, masih terdapat beberapa permasalahan dalam proses pembelajaran yang dapat dijadikan refleksi atau pertimbangan untuk perbaikan pada siklus berikutnya. Secara umum permasalahan yang muncul dapat dijabarkan sebagai berikut.

1) Pada pertemuan awal, mahasiswa masih belum mampu beradaptasi dengan model pembelajaran yang diterapkan. Beberapa mahasiswa masih terlihat bingung dan perlu dituntun dalam pengerjaan tugas yang diberikan.

2) Pada awal pertemuan, terdapat pula beberapa mahasiswa yang terlihat tidak antusias dan kurang fokus saat diskusi kelompok berlangsung. Keaktifan mahasiswa juga masih kurang. Beberapa mahasiswa terlihat masih malu bertanya baik kepada mahasiswa lain yang lebih mampu, maupun kepada dosen pengajar.

3) Interaksi dan kerja sama antar anggota kelompok belum berlangsung secara optimal. Mahasiswa masih kurang aktif dalam kegiatan diskusi kelompok untuk memecahkan masalah matematika yang dihadapi. Beberapa kelompok masih bekerja individual atau sendiri-sendiri tanpa berdiskusi dengan anggota kelompoknya. Sedangkan ada juga beberapa maahsiswa yang hanya menunggu jawaban dari teman dalam menyelesaikan masalah yang diberikan.

4) Mahasiswa masih kesulitan dalam mengerjakan latihan soal yang berupa soal cerita terutama yang berorientasi pada pemecahan masalah. hal ini terkait belum mampunya mahasiswa beradaptasi terhadap sistem yang baru. Pada saat tes, terlihat Mahasiswa hanya menjawab secara langsung tanpa menuliskan dan memahami langkah-langkah kerjanya untuk memecahkan suatu masalah

5) Masih ada beberapa mahasiswa yang terlambat mengirimkan tugas mandiri pada Google Classroom. Hal ini dikarenakan mahasiswa masih banyak yang belum terbiasa menggunakan program media aplikasi Google Classroom dan masih kesulitan dalam pengoperasiannya dalam proses pembelajaran.

Setelah mengevaluasi masalah yang ditemukan pada pelaksanaan siklus I sebelumnya, perlu dilakukan tindakan dan pendekatanpendekatan sebagai solusi untuk mengatasi permasalahan yang terjadi sebelumnya, sehingga diharapkan proses pembelajaran pada siklus II menjadi lebih optimal. Untuk mengatasi permasalahan yang ditemui pada siklus I, dilakukan beberapa strategi dan tindakan perbaikan. Pertama, adalah mahasiswa diberi penjelasan kembali mengenai strategi dan program pembelajaran yang sedang diterapkan. Hal ini dilakukan agar mahasiswa lebih paham dengan prosedur pembelajaran yang harus dilakukan sehingga memudahkan mahasiswa dalam membiasakan diri mengikuti pembelajaran model Problem Based Learning berbantuan Google Clasroom. Kedua, dilakukan bimbingan dan pengawasan secara intens dan berkelanjutan kepada tiap-tiap kelompok. Hal ini bertujuan selain untuk meningkatkan pemahaman, juga bertujuan untuk mempermudah proses adaptasi mahasiswa terhadap sistem pembelajaran yang dilakukan. Adapun strategi ketiga adalah dengan memberikan dorongan, motivasi dan sugesti agar mahasiswa aktif bersinergi dan bekerja sama dalam kelompok, serta memberikan pengertian kepada mahasiswa bahwa dengan belajar secara kelompok akan memudahkan dalam memecahkan permasalah pembelajaran yang diberikan, Strategi 
ini dilakukan dengan cara menjelaskan bahwa dalam pembelajaran, aktivitas dan sinergisitas kerja sama kelompok sangatlah penting, sebab dengan berdiskusi dengan anggota kelompok, permasalahan akan lebih mudah diatasi karena terdapat pertukaran ide dan solusi dalam pemecahan masalah. Selain meningkatkan pemahaman tentang program pembelajaran untuk memudahkan adaptasi, hal ini juga diharapkan dapat mengatasi rendahnya keaktifan siswa dalam diskusi, dimana didasarkan pada fakta bahwa "Hasil belajar akan optimal jika ada motivasi yang tepat". Karena itu motivasi dilakukan secara continyu untuk merangsang mahasiswa menjadi lebih aktif. Untuk permasalahan mengenai masih adanya beberapa mahasiswa yang malu dan takut bertanya, dosen secara aktif melakukan pendekatan kepada mahasiswa tersebut dan mendorong mahasiswa untuk mau mengungkapkan masalah yang dialami. Hal ini akan melatih keberanian dan meningkatkan rasa percaya diri mahasiswa untuk bertanya, menyampaikan pendapat, maupun dalam memberikan tanggapan terhadap pendapat yang disampaikan oleh temannya. Kemudian strategi keempat, mahasiswa diberikan penjelasan mengenai teknis pemakaian praktis dari Google Classroom dan dimotivasi dengan diberi penjelasan keuntungan menggunaan Google Clasroom sebagai aplikasi pendukung pembejalaran. Dengan penggunaan media aplikasi Google Clasroom ini sebagai media pendukung pembelajaran, mahasiswa akan mendapat banyak sekali manfaat dan kemudahan baik dari segi akses maupun proses pembelajaran itu sendiri. mahasiswa akan sangat dipermudah karena dapat mengakses materi dimana saja dan kapan saja, hanya dengan menggunakan HP/ Laptop.

Setelah dilakukan berbagai strategi dan tindakan dalam memperbaiki dan mengatasi permasalahan yang terjadi pada proses siklus I, hal tersebut ternyata berhasil meningkatkan hasil belajar matematika mahasiswa pada siklus II. Peningkatan ini terlihat dari peningkatan rata-rata skor 66,83 menjadi 73,03 dengan persentase peningkatan sebesar $9,27 \%$ dari rata-rata skor pada siklus I. Daya serap Mahasiswa secara klasikal adalah 73,03\% dan ketuntasan belajar Mahasiswa secara klasikal adalah 83,33\%, sedangkan rata-rata skor hasil belajar matematika
Mahasiswa ranah afektif adalah 3,67 atau termasuk dalam kategori baik dengan persentase peningkatan sebesar $12,23 \%$ dari rata-rata skor pada siklus I. Dari data tersebut dapat dilihat bahwa rata-rata skor hasil belajar matematika Mahasiswa ditimjau dari ranah kognitif, daya serap Mahasiswa secara klasikal, dan rata-rata skor hasil belajar matematika Mahasiswa ranah afektif sudah memenuhi kriteria yang ditetapkan yakni rata-rata hasil belajar ranah kognitif $\geq 69$, daya serap $\geq 60 \%$ ketuntasan belajar Mahasiswa $\geq 75 \%$. Disamping itu, analisis data respons Mahasiswa menunjukkan bahwa rata-rata skor respons Mahasiswa adalah sebesar 41,63 (Gambar 4).

\section{Respon Mahasiswa}

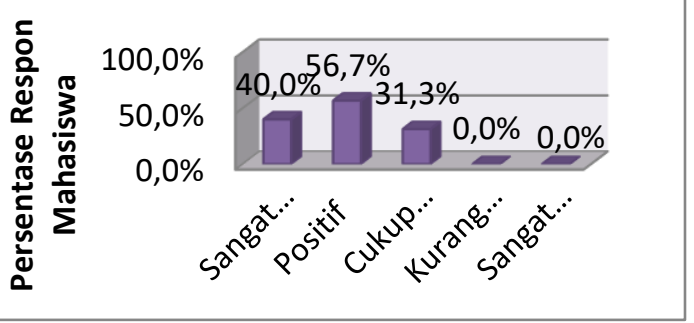

Gambar 4. Sebaran Respons Mahasiswa

Dari hasil evaluasi, berdasarkan kriteria penggolongan respons mahasiswa yang telah ditetapkan, maka respons mahasiswa terhadap impelementasi model pembelajaran Problem Based Learning dengan berbantuan Google Classroom tergolong kategori positif. Hal ini berarti bahwa Mahasiswa dapat mengakomodasi dan melaksanakan pembelajaran dengan baik setelah diterapkannya model impelementasi model pembelajaran Problem Based Learning dengan berbantuan Google Classroom. mahasiswa memandang model Problem Based Learning dengan berbantuan Google Classroom cocok diterapkan dalam pembelajaran matematika dan mampu meningkatkan pemahaman akan materi yang secara tidak langsung juga meningkatkan nilai prestasi belajar mahasiswa dalam bidang ilmu matematika. Berdasarkan penelitian tersebut maka impelementasi model pembelajaran Problem Based Learning dengan berbantuan Google Classroom dapat 
meningkatkan prestasi belajar matematika ahasiswa STMIK STIKOM Indonesia.

\section{KESIMPULAN}

Berdasarkan hasil penelitian dapat disimpulkan beberapa hal sebagai berikut:

1. Implementasi model Problem Based Learning berbantuan Google Classroom dapat meningkatkan prestasi belajar matematika mahasiswa TI STMIK STIKOM Indonesia. Hal ini terlihat dari rata-rata skor hasil belajar matematika Mahasiswa untuk ranah kognitif yaitu 60,07 pada tahap refleksi awal meningkat sebesar 11,25\% menjadi 66,83 pada siklus I, meningkat sebesar 9,27\% menjadi 73,03 pada siklus II. Sedangkan rata-rata skor hasil belajar matematika Mahasiswa untuk ranah afektif yaitu 2,83 (kategori cukup baik) pada tahap refleksi awal meningkat sebesar 18,4\% menjadi 3,27 (kategori baik) pada siklus I, meningkat sebesar $12,23 \%$ menjadi 3,67 (kategori baik) pada siklus II

2. Respons Mahasiswa terhadap penerapan model impelementasi model pembelajaran Problem Based Learning dengan berbantuan Google Classroom tergolong positif. Dari evaluasi akhir, mahasiswa menganggap sistem pembelajaran. Problem Based Learning dengan berbantuan Google Classroom memudahkan mahasiswa untuk memahami materi dengan lebih baik dan cepat. Mahasiswa juga mengingat materi lebih lama sehingga dalam memecahkan soal-soal yang diberikan, mahasiswa merasa lebih mudah dan efisien.

\section{DAFTAR PUSTAKA}

Arikunto, Suharsimi. 2008. Penelitian Tindakan Kelas. Jakarta: Bumi Aksara.

Evi, Sudiarta Suweken. 2013 Pengaruh Model Pembelajaran Berbasis Masalah (Problem Based Learning) Berbantuan Pertanyaan Metakognitif Terhadap Prestasi Belajar Matematika Siswa Ditinjau Dari Motivasi Berprestasi. Jurnal Pendidikan matematika vol 2 tahun 2013
Gheytasi, M., Azizifar, A., \& Gowhary, H. 2015. The Effect of Smartphone on the Reading Comprehension Proficiency of Iranian EFL Learners. Procedia - Social and Behavioral Sciences, 199, 225-230. https://doi.org/ 10.1016/J.SBSPRO.2015.07.510

Kementrian pendidikan dan kebudayaan Republik Indonesia. 2017. UU No 20 Tahun2003. http://kemdikbud.go.id/index.php/peraturan 1/8-uu-undang-undang/12-uu-no-20-tahun2003-tentang-sistem-pendidikan-nasional diakses 7 januari 2020

Maharani, Nia, Sepdyana. 2019. Penggunaan Google Classroom sebagai Pengembangan Kelas Virtual dalam Keterampilan Pemecahan Masalah Topik Kinematika pada Mahasiswa jurusan Sistem Komputer. PENDIPA Journal of Science Education, 2019: 3(3), 167-173

Muslik, Ahmad. 2019. Google classroom Sebagai Alternatif Digitalisasi Pembelajaran Matematika Di Era Revolusi Industri 4.0.

Jurnal Diklat Teknis Pendidikan dan Keagamaan Vol. 7, No. 2, e-ISSN 2623-1190 Sabran. 2018. Keefektifan Google Classroom Sebagai Media Pembelajaran https://ojs.unm.ac.id/semnaslemlit/article/vie w/8256 diakses bulan februari 2020

Shofiyah dan Wulandari. 2018. Model Problem Based Learning (PBL) Dalam Melatih Scientific Reasoning Siswa. JPPIPA (Jurnal Penelitian Pendidikan IPA), Vol. 3, No. 1, 33-38 e-ISSN: 2549-2209

Suherman, Erman dkk. 2003. Strategi Pembelajaran Matematika Kontemporer. Bandung: PT Remaja Rosdakarya.

Sumini. 2015. Penelitian Tindakan Kelas dan dasar-dasar Profesi guru. Universitas Sanata Dharma, Yogyakarta. 